\title{
Fast response of fungal and prokaryotic communities to climate change manipulation in two contrasting tundra soils
}

\author{
Jana Voříšková ${ }^{1,2,3^{*}}$ D, Bo Elberling ${ }^{1}$ and Anders Priemé $e^{1,4}$
}

\begin{abstract}
Background: Climate models predict substantial changes in temperature and precipitation patterns across Arctic regions, including increased winter precipitation as snow in the near future. Soil microorganisms are considered key players in organic matter decomposition and regulation of biogeochemical cycles. However, current knowledge regarding their response to future climate changes is limited. Here, we explore the short-term effect of increased snow cover on soil fungal, bacterial and archaeal communities in two tundra sites with contrasting water regimes in Greenland. In order to assess seasonal variation of microbial communities, we collected soil samples four times during the plant-growing season.

Results: The analysis revealed that soil microbial communities from two tundra sites differed from each other due to contrasting soil chemical properties. Fungal communities showed higher richness at the dry site whereas richness of prokaryotes was higher at the wet tundra site. We demonstrated that fungal and bacterial communities at both sites were significantly affected by short-term increased snow cover manipulation. Our results showed that fungal community composition was more affected by deeper snow cover compared to prokaryotes. The fungal communities showed changes in both taxonomic and ecological groups in response to climate manipulation. However, the changes were not pronounced at all sampling times which points to the need of multiple sampling in ecosystems where environmental factors show seasonal variation. Further, we showed that effects of increased snow cover were manifested after snow had melted.

Conclusions: We demonstrated rapid response of soil fungal and bacterial communities to short-term climate manipulation simulating increased winter precipitation at two tundra sites. In particular, we provide evidence that fungal community composition was more affected by increased snow cover compared to prokaryotes indicating fast adaptability to changing environmental conditions. Since fungi are considered the main decomposers of complex organic matter in terrestrial ecosystems, the stronger response of fungal communities may have implications for organic matter turnover in tundra soils under future climate.
\end{abstract}

Keywords: Microbial communities, Climate warming, Enhanced precipitation, Snow fence, Microbial ecology, Fungi, Bacteria, Arctic soil, Greenland

\footnotetext{
*Correspondence: jvoriskova1@gmail.com

${ }^{1}$ Center for Permafrost (CENPERM), Department of Geosciences and Natural

Resource Management, University of Copenhagen, Copenhagen, Denmark

${ }^{2}$ Department of Geochemistry, Geological Survey of Denmark and Greenland

(GEUS), Copenhagen, Denmark

Full list of author information is available at the end of the article
}

(c) The Author(s). 2019 Open Access This article is distributed under the terms of the Creative Commons Attribution 4.0 International License (http://creativecommons.org/licenses/by/4.0/), which permits unrestricted use, distribution, and reproduction in any medium, provided you give appropriate credit to the original author(s) and the source, provide a link to the Creative Commons license, and indicate if changes were made. The Creative Commons Public Domain Dedication waiver (http://creativecommons.org/publicdomain/zero/1.0/) applies to the data made available in this article, unless otherwise stated. 


\section{Introduction}

Arctic tundra represents a globally significant biome covering 7.3 million $\mathrm{km}^{2}$ ( $\sim 5 \%$ of Earth's land area). It is characterized by low temperatures, a short plant-growing season and a long dark winter with sub-zero temperatures. In general, tundra soils contain high quantities of organic matter [47] due to the constrained decomposition processes caused by low temperatures and strong nutrient limitations [45]. This pool of organic matter can play an important role in the global terrestrial carbon (C) cycle if mineralized [76]. Microorganisms are the main drivers of degradation of soil organic $\mathrm{C}$ (SOC mineralization) into greenhouse gases $[48,83]$. Global climate changes, including warming and altered precipitation, are predicted to be the most pronounced at northern latitudes [12, 50]. Therefore, the response of tundra soil microorganisms to these changes will have important consequences for ecosystem functioning and climate change feedbacks.

Nutrient cycling and the decomposition of organic matter in various habitats are driven by a diverse group of microorganisms (fungi, bacteria, archaea, and microeukaryotes). Fungi are considered the main decomposers in terrestrial ecosystems in part due to their production of a wide range of lignocellulytic enzymes with abilities to attack complex parts of soil organic matter [84]. Bacteria and archaea, unlike fungi, are rather involved in earlier stages of organic matter decomposition and a faster consumption of simple carbon compounds [60]. Evidence suggests that soil temperature and moisture are important environmental parameters affecting microbial activity $[11,79]$ and SOC decomposition rates $[39,75]$. Climate change in cold regions may thus change the activity of soil microbial communities and boost their ability to decompose $\mathrm{SOC}$, which may alter $\mathrm{C}$ storage in Arctic soils and influence $\mathrm{CO}_{2}$ concentration in the atmosphere [14].

Climate change is projected to increase winter precipitation as snow in northern latitudes during the coming decades [50]. The depth and duration of seasonal snow cover seem to be important parameters affecting microorganisms in tundra soil $[17,74]$ and thus SOC decomposition. The snow pack serves as an insulation layer for soil and vegetation [33], protecting the soil from extremely low air temperatures that occur during the Arctic winter. Deeper snow cover enhances the isolation effect, which rises winter soil temperature [59] leading to increased microbial activity [74]. The influence of snow cover on soil ecosystems is not limited to the winter season and can persist until late summer by affecting e.g. soil moisture, the length of plant growing season, or nutrient availability $[24,87,90,95]$. Increased snow cover has been shown to affect tundra soil respiration [59, 94], density of shrub cover [62, 95], litter decomposition [13], and nutrient dynamics [74, 77] suggesting that deeper snow pack may potentially alter microbial communities. These findings are supported by a recent study by Xue et al. [96] reporting increased abundance of microbial functional genes involved in SOC decomposition as a result of deeper snow cover in tundra soil. Several recent studies assessing the effect of increased snow cover on microbial communities involved only specific groups of microbes [20, 57, 61]. However, to better understand and quantify tundra soil ecosystem processes, it is essential to address both fungal and prokaryotic communities at the same time. Also, most studies are performed following several years of in situ ecosystem manipulation $[58,73,78]$ and, thus, do not investigate fast (within one-two years) and immediate responses of tundra soil microbial communities to enhanced snow cover. In contrast to long-term climate manipulation treatments, where the ecological drivers of microbial communities are mostly changes in soil chemical properties and/or vegetation cover, the changes of microbial communities following short-term treatment are mainly associated with habitat loss and opening of new niches that may be colonized by rapidly responding microbes [9, 30, 38, 67]. Since the mechanisms driving microbial communities are different for short- and longterm climate manipulation experiments, both types of manipulation treatments need to be studied. Today, soil microbial communities form one of the largest uncertainties to climate model predictions [36]. Thus, understanding the short-term effect of increased winter precipitation on the dynamics and functioning of soil microbial communities, major decomposers of SOC, is necessary for predicting if Arctic tundra soils become a sink or source of $\mathrm{CO}_{2}$ under future climates.

The main aim of this study was to characterize compositional changes in fungal and prokaryotic communities in response to increased snow cover in two Arctic tundra soils with contrasting water regimes and vegetation types (a dry mixed-shrub heath and a wet fen, respectively). In order to mimic increased winter precipitation, we implemented a snow manipulation experiment using snow fences to trap drifting snow during winter on Disko Island, Western Greenland [13]. To our knowledge, this is the first study addressing short-term effects of increased winter precipitation simultaneously on fungal, bacterial and archaeal communities in tundra soil. The results of Wallenstein et al. [92] indicate that activity of extracellular enzymes in tundra soils varies with season and very limited information is available on temporal dynamics of microbial communities in these type of soils therefore we repeated soil sampling at four time points between June and October which is snow-free period in our study site. We hypothesized that microbial community diversity will be quickly and markedly affected by increased snow cover mirroring changes in soil moisture and nutrient availability induced by deepened snow and that this effect will also 
be manifest in the snow-free period. Furthermore, we hypothesized that the bacterial community composition and richness will be more affected by short-term snowmanipulation compared to the fungal community as bacteria generally have higher growth and turnover rates than fungi [80] and thus a potentially faster adaptation to the new conditions. Based on results from the same experimental site showing that deeper snow during the winter significantly increases the rate of litter decomposition [13] we hypothesized that snow manipulated plots will exhibit higher abundance of saprotrophic and plant pathogenic fungi compared to control sites.

\section{Methods}

\section{Study site and experimental set-up}

The study area was in the Blæsedalen valley $\left(69^{\circ} 16^{\prime} \mathrm{N}\right.$, $53^{\circ} 27^{\prime} \mathrm{W}$ ) on Disko Island in Western Greenland. The area has low-arctic climate with a mean annual air temperature of $-3.0^{\circ} \mathrm{C}$, the warmest month is July with a mean temperature of $7.9^{\circ} \mathrm{C}$ and the coldest month is March with a mean temperature $-14^{\circ} \mathrm{C}$ (period 1991-2011). The mean annual amount of precipitation is $\sim 400 \mathrm{~mm}$ of which $40 \%$ fall in form of snow (1994-2006), measured at Arctic Station, approximately $3 \mathrm{~km}$ from the study area [46]. The study area lies within the discontinuous permafrost zone.

The snow manipulation experiment was established at two tundra sites approximately $200 \mathrm{~m}$ apart. The first site was dry mixed-shrub heath dominated by Vaccinium uliginosum, Betula nana, Salix glauca, Empetrum nigrum, and Cassiope tetragona, and soil consists of basaltic rock fragments covered by a thin $(5-10 \mathrm{~cm})$ organic horizon - indicated throughout the manuscript as the dry site (D). The second site was wet fen dominated by Carex aquatilis ssp. stans, Carex rariflora, Eriophorum angustifolium, Paludella squarrosa, Tomentypnum nitens, Salix arctophila and Dryas octopetala, and soil consists of basaltic rock fragments covered by a $\sim 20$-cm peat layer - indicated as the wet site (W). At both sites, the snow depth manipulation experiment included six replicate blocks providing sufficient statistical power. Each block contained a 14.7-m-long and $1.5-\mathrm{m}$-tall snow fence to create snowdrifts on the leeward (south) side of the fences during winter (indicated as snow manipulation - S), while the windward side of the snow fence represented ambient snow conditions (indicated as control - C). Snow depth on manipulated side of snow fences was on average $150 \mathrm{~cm}$, snow depth on control side was on average $70 \mathrm{~cm}$, and these conditions lasted for at least 3 months during the winter period. Snow fences were established in June 2012 and July 2013 at the dry site and the wet site, respectively. Soil temperatures $(5 \mathrm{~cm}$ depth) were measured continuously in snow manipulation and control plots of three blocks, using TinyTag PB-5001 thermistor probes (Gemini Data Loggers, Chichester, UK) and logged every hour. The sites have been studied previously with respect to the effect of increased snow cover on litter decomposition [13], litter-decomposing fungi [20] and methane fluxes $[27,63]$.

\section{Sample collection and processing}

Sampling of the topsoil $(0-5 \mathrm{~cm})$ at both sites was repeated four times during the entire snow-free period of 2014: June 23-26 (immediately after snow melt on both sides of snow fences), July 18-22, September 07-10, and October $10-12$. Five soil cores $(2 \mathrm{~cm}$ in diameter) were collected at control and manipulated side of each snow fence (six replicates at each site) at a distance of ca. $1 \mathrm{~m}$ from each other in a parallel line with the snow fence in a distance of ca. $2.5 \mathrm{~m}$ from the fence. Soil samples were processed within $24 \mathrm{~h}$ after sampling in the laboratory of nearby Arctic Station. The material from the five replicate soil cores was combined and homogenized and woody roots were removed. Subsamples for DNA isolation, chemical analyses and quantification of fungal biomass were frozen at $-20^{\circ} \mathrm{C}$, and DNA was isolated within 1 week in the laboratory of Arctic Station using Nucleospin Soil Kit (Macherey-Nagel, Düren, Germany). Three DNA extractions were performed from each sample and mixed afterwards. Approximately $0.25 \mathrm{~g}$ of soil was used for each DNA extraction. All samples were kept frozen in insulated boxes during the transportation to Copenhagen where they were stored at $-20^{\circ} \mathrm{C}$ until further analysis.

\section{Soil properties and fungal biomass}

Records of soil temperature at $5 \mathrm{~cm}$ soil depth were carried out using a portable thermometer (Spectrum Technologies, Aurora, IL, USA) [20]. Soil samples were weighed into tin capsules and analyzed for total $\mathrm{C}$ and $\mathrm{N}$ on Isoprime isotope ratio mass spectrometer (Elementar, Langenselbold, Germany) coupled to a Eurovector $\mathrm{CN}$ elemental analyzer (Eurovector, Pavia, Italy). Soil organic matter (SOM) was estimated through loss of ignition at $550^{\circ} \mathrm{C}$. Soil $\mathrm{pH}$ was measured by adding double deionised $\mathrm{H}_{2} \mathrm{O}$ to dry soil in a 1:10 ratio, and water content was calculated by freeze-drying of soil subsamples. Total ergosterol was extracted from $0.25 \mathrm{~g}$ of freeze-dried soil with $10 \% \mathrm{KOH}$ in methanol and analyzed by high-performance liquid chromatography using a method modified from Bååth [7].

\section{Illumina amplicon sequencing of fungal and bacterial communities}

For fungal community analysis, the primers gITS7/ITS4 [49] were used to amplify the ITS2 region of rRNA operon, and for prokaryotic community analysis, primer pair 515F/806R targeting the V4 region of $16 \mathrm{~S}$ rRNA gene was used [19]. PCR amplifications were performed with primers containing template-specific sequences extended by a 2-nt linker and 4-6-nt barcode. Each of three independent $10 \mu \mathrm{L}$ reactions per DNA sample contained $2 \mu \mathrm{L}$ 
of $5 \mathrm{x}$ polymerase buffer, $1 \mu \mathrm{L}$ of $10 \mathrm{mg} \mathrm{mL}^{-1}$ bovine serum albumin, $0.5 \mu \mathrm{L}$ of each primer $(0.01 \mathrm{mM}), 0.2 \mu \mathrm{L}$ of dNTPs $(10 \mathrm{mM}), 0.1 \mu \mathrm{L}$ of PCRBIO HiFi Polymerase (PCR Biosystems, London, UK), $0.5 \mu \mathrm{L}$ of template DNA (DNA concentration $10-100 \mathrm{ng} / \mu \mathrm{L}$ ), and $5.2 \mu \mathrm{L}$ of $\mathrm{H}_{2} 0$. The cycling conditions were $95^{\circ} \mathrm{C}$ for $1 \mathrm{~min} ; 35$ cycles of $95^{\circ} \mathrm{C}$ for $15 \mathrm{~s} ; 56^{\circ} \mathrm{C}$ for $20 \mathrm{~s}$; and $72{ }^{\circ} \mathrm{C}$ for $20 \mathrm{~s}$, followed by $72^{\circ} \mathrm{C}$ for $5 \mathrm{~min}$ for primers gITS7/ITS4, and $95^{\circ} \mathrm{C}$ for $1 \mathrm{~min} ; 30$ cycles of $95^{\circ} \mathrm{C}$ for $15 \mathrm{~s} ; 50^{\circ} \mathrm{C}$ for $20 \mathrm{~s}$; and $72^{\circ} \mathrm{C}$ for $20 \mathrm{~s}$, followed by $72{ }^{\circ} \mathrm{C}$ for $5 \mathrm{~min}$ for primers $515 \mathrm{~F} /$ 806R. PCR products from three PCR replicates were pooled and purified using HighPrep ${ }^{\text {tx }}$ PCR clean up system (MAG$\mathrm{BIO}$, Gaithersburg, MD, USA). The concentration of PCR products was quantified using the Qubit $^{\circ}$ 2.0 Fluorometer (Life Technologies, Carlsbad, CA, USA). PCR products were mixed equimolarly and Illumina adapter sequences were ligated on amplicons using TruSeq DNA PCR-Free LT Sample Prep Kit (Illumina, San Diego, CA, USA). The amplicon library was subjected to sequencing on Illumina MiSeq $2 \times 250$ bp paired-end platform in the National High-throughput DNA Sequencing Centre (Copenhagen, Denmark). Sequencing data are available in the MGRAST public database (http://metagenomics.anl.gov/, dataset numbers 4782666.3 and 4782667.3).

\section{Bioinformatic analyses}

Illumina sequencing data were processed using the combination of pipelines proposed by Bálint et al. [8] and Větrovský and Baldrian [85]. Paired-end reads were merged using fastq-join [3]. The ITS region of fungal sequences was extracted using ITSx [10]. Sequences were clustered at $97 \%$ similarity level using UPARSE [32]. During the clustering chimeric sequences were discarded. Singleton sequences were removed from the dataset and consensus sequences were constructed for each operational taxonomic unit (OTU). Closest hits of fungal and bacterial sequences were identified using UNITE database [1] and SILVA reference database release 119 [72], respectively.

\section{Diversity and statistical analysis}

The most abundant OTUs representing $80 \%$ of all fungal or prokaryotic sequences were used for calculation of diversity estimates, providing combined information on OTU richness and evenness in an individual samples [86]. These estimates were calculated based on datasets containing 9000 fungal and 2200 bacterial randomly selected sequences from each sample. OTU accumulation curves were calculated using R package vegan [64]. Venn diagrams, where OTUs with $>0.01 \%$ abundance were considered as present, were calculated using Venn Diagram Plotter (https://omics.pnl.gov/software/venndiagram-plotter). The data were analyzed with a combination of constrained and unconstrained multivariate statistical methods in order to account for total variation in the data and variation explainable by the environmental data. Partial principal component analysis (PCA) where snow fence block was set as a covariate and redundancy analysis (RDA) with interactive forward selection and 999 Monte Carlo permutations were used to explain the variation in the data. Both analyses were performed in the multivariate data analysis software CANOCO 5.0 [82]. Significant community differences were tested by analysis of similarity (ANOSIM) with Bray-Curtis dissimilarity of relative abundances calculated using software PRIMER 6 [56]. Soil properties and microbial diversity were tested for differences using paired $\mathrm{t}$-tests following square root transformation of the data. Statistically significant differences in abundance of OTUs or higher-level microbial taxa between control and manipulated sites were tested by DESeq 2 with Benjamini-Hochberg correction [55, 93].

\section{Results \\ Soil properties}

The soil properties significantly differed between the dry and the wet sites. Water content averaged 53 and $80 \%$ $\left(P=6 \times 10^{-18}\right)$, $C$ content 20.1 and $26.8 \%\left(P=6 \times 10^{-7}\right)$, $\mathrm{N}$ content 0.60 and $1.46 \%\left(P=2 \times 10^{-16}\right), \mathrm{pH} 5.15$ and $5.9\left(P=1 \times 10^{-21}\right)$ and organic matter content 39.3 and $57.3 \%\left(P=1 \times 10^{-10}\right)$ at the dry and wet site respectively (Additional file 1). However, we found no significant differences in soil chemical properties between control and snow manipulated plots at any of the two sites. Soil temperature (measured at $5 \mathrm{~cm}$ depth) was higher in snow-manipulated plots compare to control plots during the snow covered period and the difference was more pronounced at the dry site compared to the wet site (Additional file 2) [20]. The mean annual soil temperatures in $5 \mathrm{~cm}$ depth were $0.02{ }^{\circ} \mathrm{C}$ and $1.06{ }^{\circ} \mathrm{C}$ in the snow-manipulated plots and $-1.33^{\circ} \mathrm{C}$ and $0.68{ }^{\circ} \mathrm{C}$ in the control plots at the dry and wet site respectively.

\section{Fungal communities}

The analysis of fungal community was performed with 2 , 307,725 sequences that remained after quality filtering, and removal of chimeric and non-fungal sequences. An average of 24,039 sequences was obtained (minimum of 9324) per sample. OTU accumulation curves are shown in Additional file 3. Fungal diversity (expressed as the number of OTUs that represented $80 \%$ of all sequences in each sample calculated at 9000 sequences per sample) was significantly higher $\left(P=1 \times 10^{-9}\right)$ at the dry site $(48.5 \pm 1.6)$ compared to the wet site $(33.2 \pm 1.3)$ (Fig. 1). Fungal diversity at the dry site was significantly lower $(P=0.032)$ in control plots $(45.6 \pm 2.2$ OTUs representing $80 \%$ of sequences) compared to snow-manipulated plots (51.3 \pm 2.1 OTUs representing $80 \%$ of sequences) 

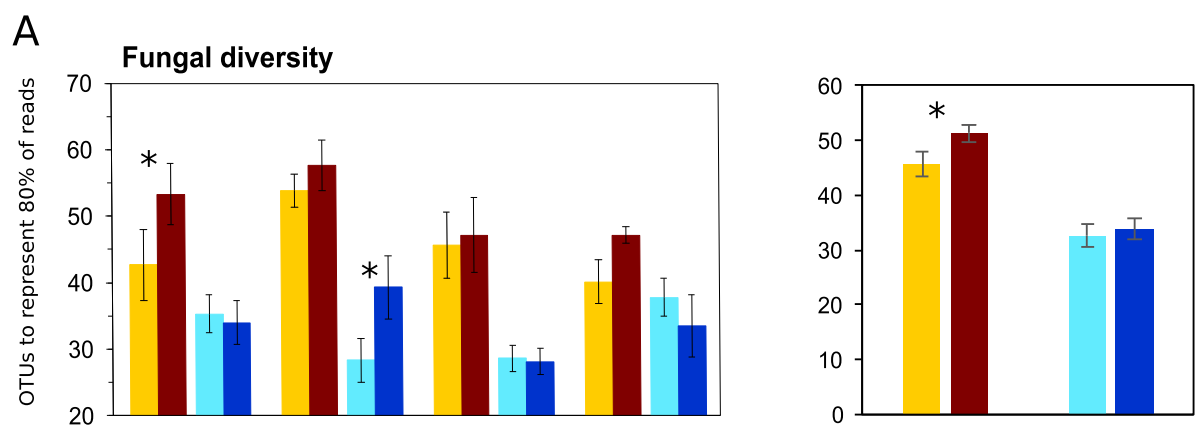

B
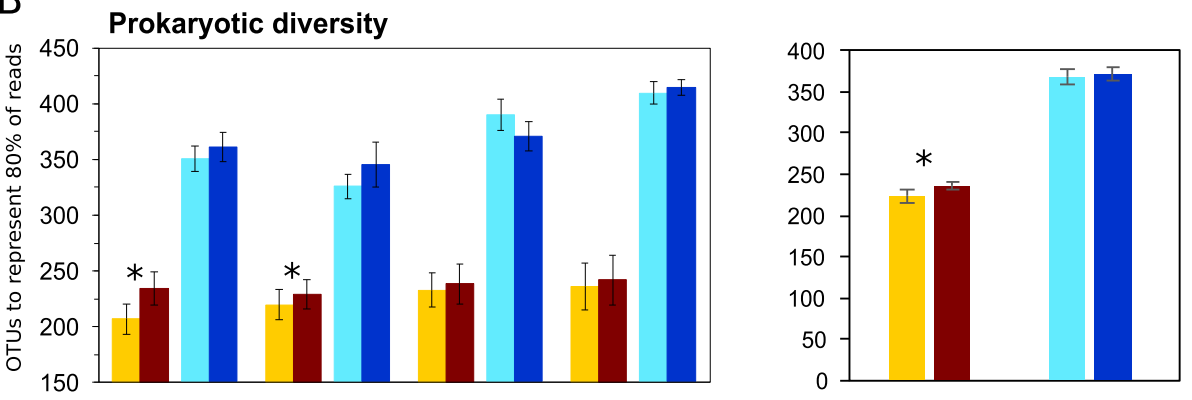

C
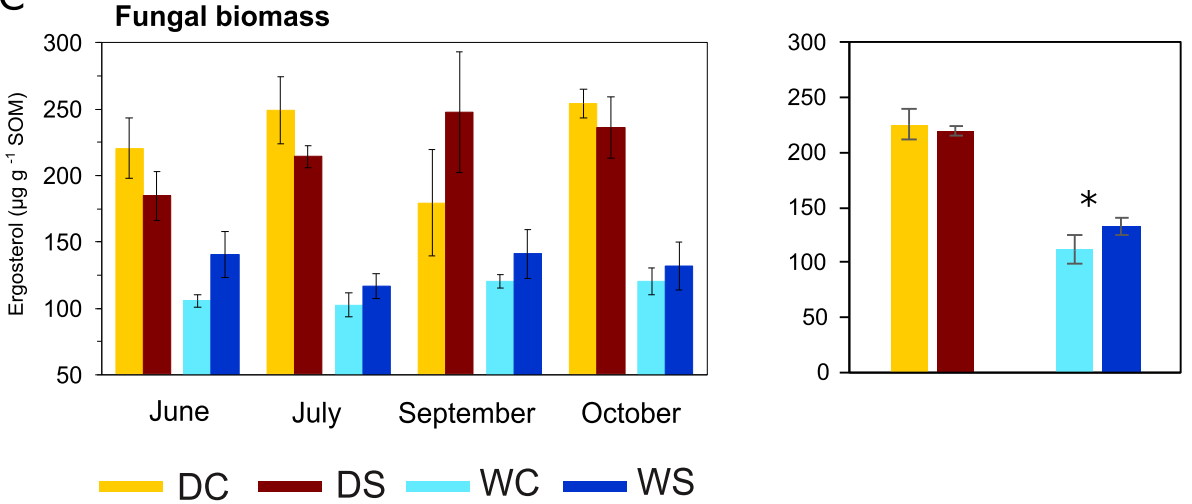

Fig. 1 Fungal (a) and bacterial (b) diversity estimates and fungal biomass (ergosterol content) (c) in the dry (D) and the wet (W) tundra soil in control (C) and snow-manipulated (S) plots by season and as a seasonal average (column chart). Diversity is expressed as the number of the most abundant OTUs (operational taxonomic units), which represented $80 \%$ of all sequences. The data represent the means with standard errors ( $n=$ 6), for seasonal average $(n=24)$. Statistically significant effects $(P<0.05)$ of treatment between $C$ and $S$ at a specific site are indicated by asterisk

with the most pronounced difference in June $(P=0.027)$. Similarly to fungal diversity, fungal biomass (expressed as ergosterol content) was substantially higher $(P=1 \times$ $\left.10^{-12}\right)$ at the dry site $\left(223 \pm 9.7 \mu \mathrm{g}\right.$ ergosterol $\left.\mathrm{g}^{-1} \mathrm{SOM}\right)$ compared to the wet site $\left(122 \pm 4.6 \mu \mathrm{g}\right.$ ergosterol $\mathrm{g}^{-1}$ SOM). Contrary to fungal diversity, fungal biomass showed significant differences $(P=0.031)$ at the wet site, where the biomass was the largest in snow-manipulated plots (Fig. 1).

The overall fungal community was largely comprised of the Basidiomycota (41.6\%) and Ascomycota (32.9\%) (Fig. 2). Mucoromycotina comprised of $1.07 \%$ of the fungal community and detected Glomeromycota and Chytridiomycota represented less than $0.5 \%$ of the sequences. PCA (principal component analysis) of control plots from combined dataset of the dry and the wet sites showed that the two sites harbored very distinct fungal populations and that the difference was driven by the soil chemical properties (Fig. 3). Only $10 \%$ of fungal OTUs were present at both the dry site and the wet site (Additional file 4). Therefore, we analyzed the data from the two sites separately to be able to target the effect of increased snow cover on the fungal communities. At the the dry site, Ascomycota represented $49.6 \%$ of identified sequences whereas Basidiomycota represented only $20.4 \%$. Here, the most abundant fungal orders were ascomycetous Helotiales (13.6\%), Chaetothyriales (11.0\%), Archaeorhizomycetales (6.9\%) and basidiomycetous Agaricales (12.3\%). Contrary to the dry site, the wet site contained distinctively more sequences belonging to 


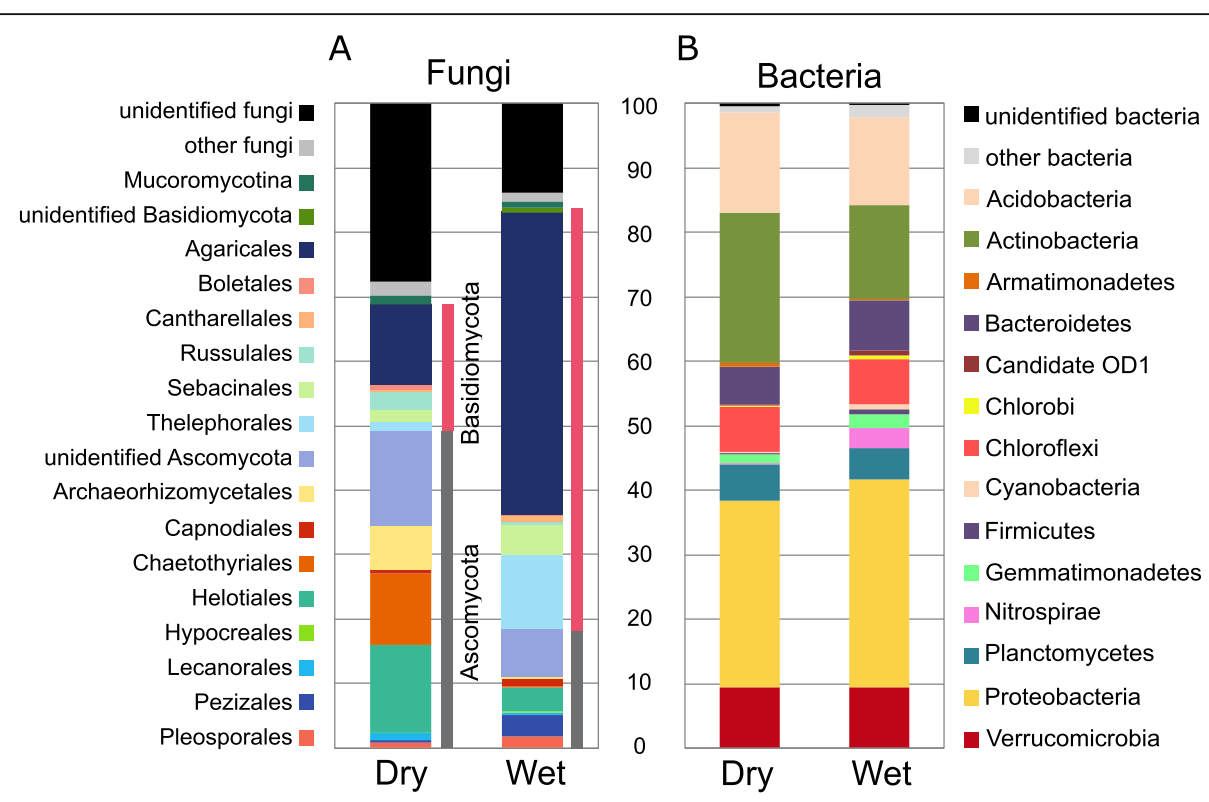

Fig. 2 Phylogenetic assignment of fungal (a) and bacterial (b) sequences from the dry and the wet tundra (control sites only). The data represent the mean abundances from four time points $(n=24)$

Basidiomycota (66.2\%) with order Agaricales representing almost half of all sequences; and Ascomycota showed lower relative abundance representing only $18.7 \%$ of identified fungal community (Fig. 2). Ectomycorrhizal, saprotrophic and lichenized fungi showed similar abundance at the dry site, whereas the wet site was dominated by the sequences belonging to ectomycorrhizal fungi (Fig. 4b). The effect of season on entire fungal community composition was rather minor (Fig. 5) therefore we analyzed the response of fungi to increased snow cover both for individual time points $(n=6)$ and for pooled samples across all time points $(n=24)$.

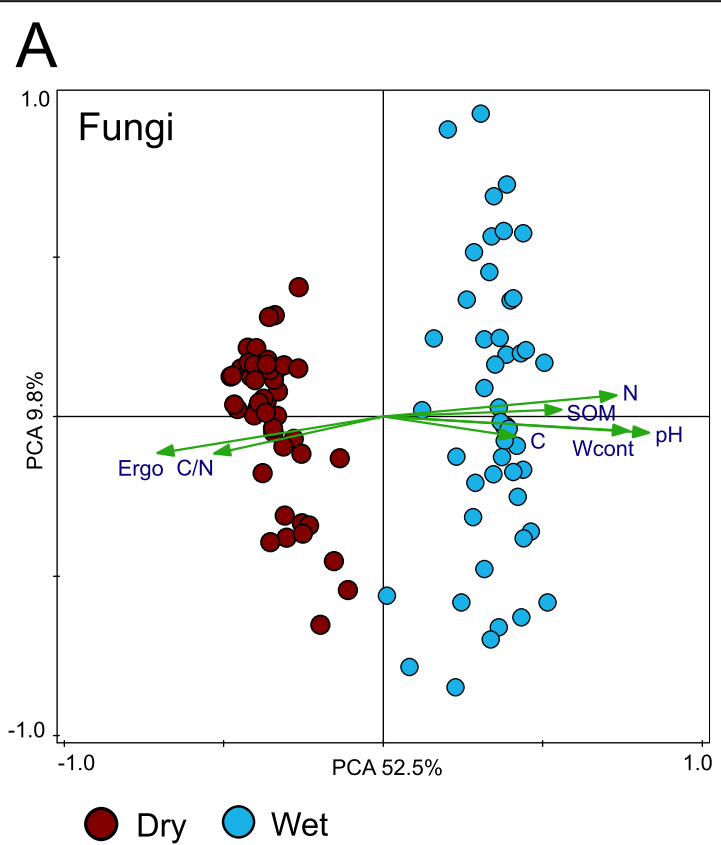

B

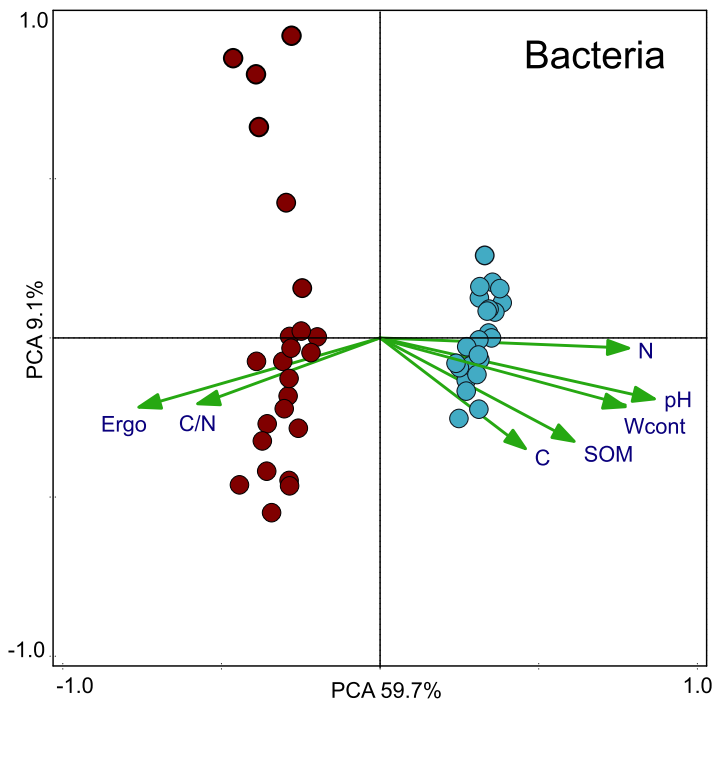

Fig. 3 Principal component analysis (PCA) of relative abundances of fungal (a) and bacterial (b) genera from control plots and environmental variables. All genera with $>0.01 \%$ abundance in the dry or the wet tundra soil were considered. Ergo, ergosterol; N, nitrogen; C, carbon; SOM, soil organic matter; Wcont, water content 
A
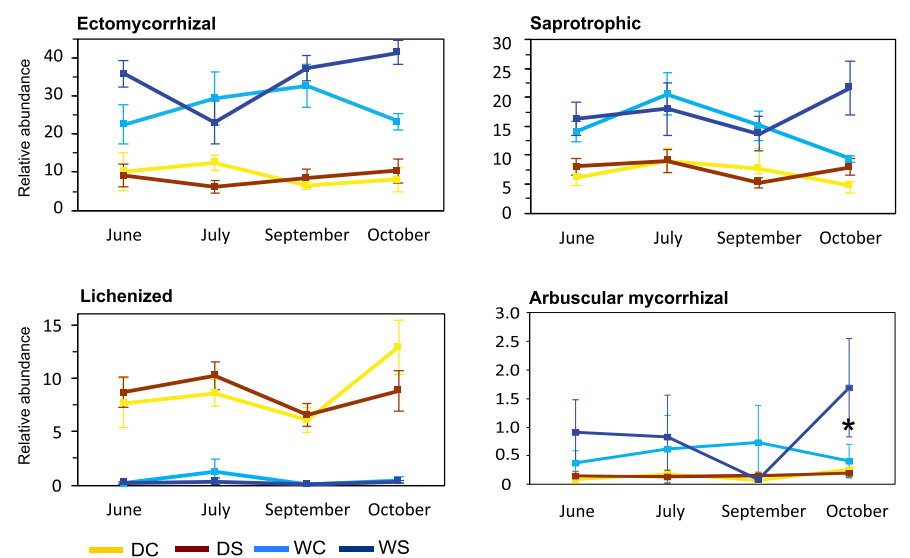

Fig. 4 Proportion of sequences belonging to different fungal ecological groups in the dry (D) and the wet (W) tundra soil in control (C) and snow-manipulated (S) plots by season (a) and as a seasonal average (b) with the chart area corresponding to the ergosterol content (pie chart). The data represent the means with standard errors $(n=6)$, for seasonal average $(n=24)$. Statistically significant effects of treatment between $C$ and $\mathrm{S}$ are indicated by asterisk (DESeq, Benjamini-Hochberg correction, $P<0.05$ )

The effect of increased-snow cover on fungal communities was profound: only $46 \%$ of fungal OTUs on the dry site and $38 \%$ on the wet site were shared between snow-manipulated plots and controls (Additional file 4), shared OTUs were represented by $96 \%$ of sequences. Six (dry site) and six (wet site) out of the thirty most abundant fungal OTUs showed statistically significant differences $(P<0.05)$ in the abundance between manipulated and control plots (Additional file 5) across all time points. The eighth most abundant OTU at the dry site assigned to lichenized Lecanoromycetes was significantly $(P=0.004)$ less abundant in manipulated plots (1.2\%) compared to control plots (1.7\%), whereas the second most abundant OTU from the wet site, the ectomycorrhizal Inocybe, had five times higher abundance $\left(P=4 \times 10^{-12}\right)$ in increased-snow plots compared to control (Additional file 5 - data for seasonal average).
B
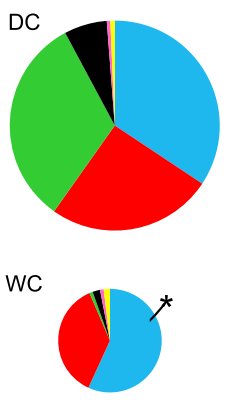

Ectomycorrhizal

Saprotrophic

Lichenized

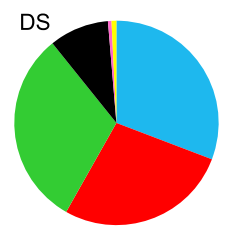

WS

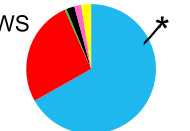

Plant pathogen

Ericoid mycorrhizal

Arbuscular mycorrhizal
At both sites, PCA showed a separation of fungal communities between the treated and control plots (Fig. 6) and the analysis of similarities (ANOSIM) based on Bray-Curtis distance revealed that the OTU composition was significantly different between the fungal communities found in ambient and manipulated plots at both sites (dry site $\mathrm{R}=0.80, P=0.01$; wet site $\mathrm{R}=$ $0.72, P=0.01)$. Results of redundancy analysis (RDA) of the 40 most abundant fungal OTUs showed that snow manipulation treatment had significant effect on the fungal communities and explained 8.1 and $10 \%$ of variability at the dry and the wet sites, respectively (Fig. 5). In total, 294 fungal genera were identified in the whole dataset. The most abundant fungal genera significantly affected by snow manipulation were Inocybe $(P=0.002)$, Camarophyllus $\left(P=3 \times 10^{-7}\right)$, Tomentella $(P=0.002)$, Chalara $(P=0.002)$, Peltigera $\left(P=6 \times 10^{-}\right.$

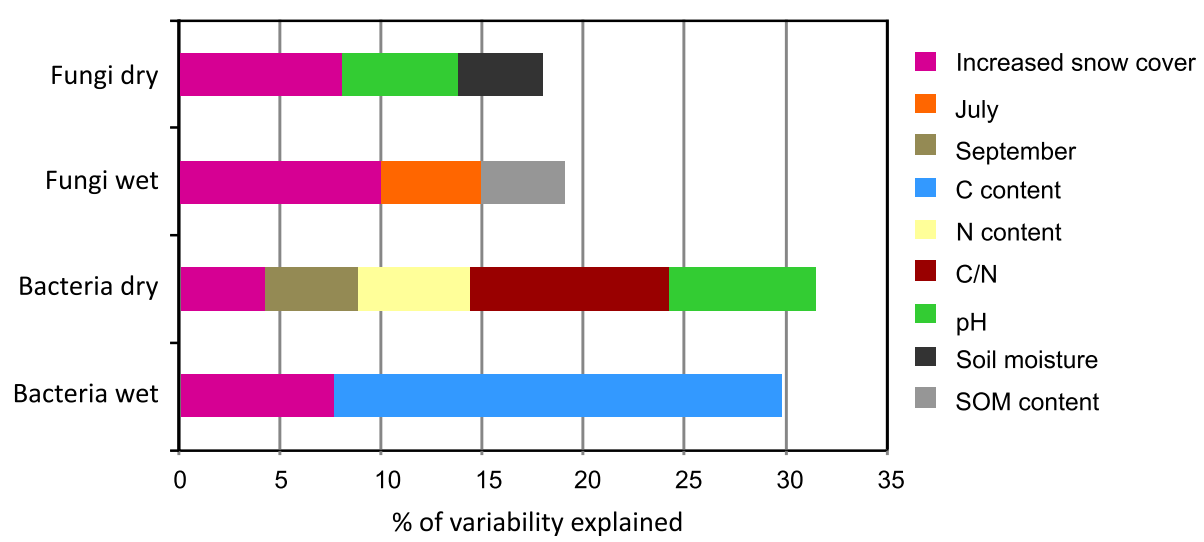

Fig. 5 Results of redundancy analysis (RDA) of the 40 most abundant bacterial and fungal OTUs from the dry and the wet tundra soil. Depicted parameters had significant $(P<0.05)$ effect on variation of bacterial or fungal community. C (carbon), N (nitrogen), SOM (soil organic matter) 

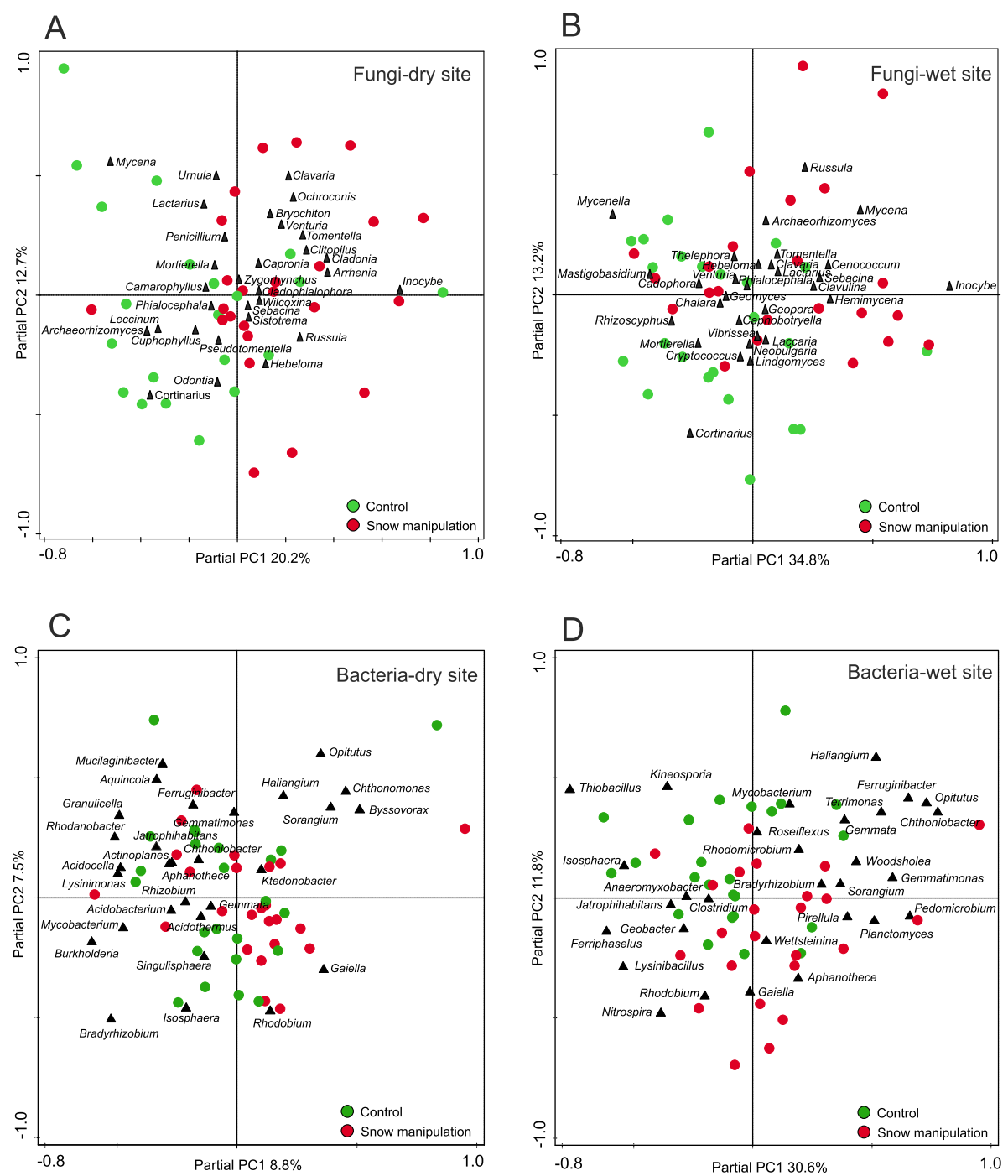

Fig. 6 Partial principal component analysis (PCA) of relative abundances of the 30 most abundant fungal genera from the dry site (a) and the wet site (b) and bacterial genera from the dry site (c) and the wet site (d), snow fence block was set as a covariate

$\left.{ }^{12}\right)$ and Rhodotorula $(P=0.025)$ at the dry site and Inocybe $(P=0.049)$, Russula $\left(P=7 \times 10^{-6}\right)$, Archaeorhizomyces $(P=0.019)$, Mycena $\left(P=9 \times 10^{-6}\right)$, Cenococcum $(P=0.047)$ and Clavaria $(P=0.001)$ at the wet site (Fig. 7). Fungal communities showed temporal variation during the snow-free period in response to the snowmanipulation treatment (Additional file 6). Fungal community collected during October was the most affected by increased snow cover compared to other seasons (Fig. 4a, Additional files 5 and 6). Ectomycorrhizal fungi inhabiting the wet site showed significantly higher abundance $(P=0.001)$ in treated plots compared to control plots (Fig. 4b). Also, the wet site in October showed significant differences $(P=0.033)$ in abundance of arbuscular mycorrhizal fungi (Fig. 4a).

\section{Prokaryotic communities}

The analysis of prokaryotic community was performed with $1,214,686$ sequences that remained after quality filtering, and removal of chimeric sequences and sequences not belonging to prokaryotes. An average of 12,653 sequences was obtained (minimum of 3098) per sample. OTU accumulation curves are shown in Additional file 3. Bacterial diversity (expressed as the number of OTUs that represented $80 \%$ of sequences in each sample calculated at 2200 sequences per sample) was substantially lower $\left(P=5 \times 10^{-23}\right)$ at the dry site $(230 \pm 5.7)$ compared to the wet site (370 \pm 6.0). At the dry site, bacterial diversity showed significant changes $(P=0.022)$ between control $(224 \pm 7.9)$ and snowmanipulated $(236 \pm 8.1)$ plot with the most pronounced differences in June $(P=0.012)$ and July $(P=0.042)$ (Fig. 1). 

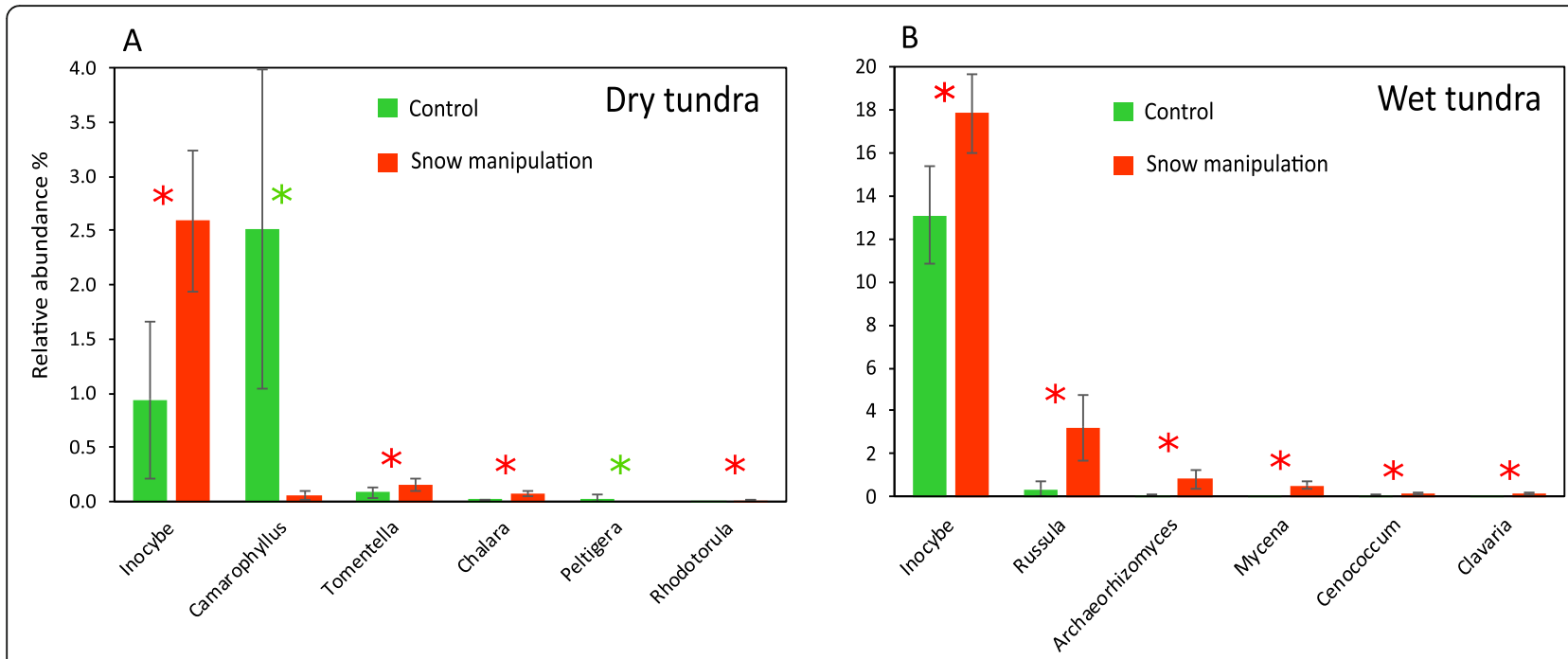

Fig. 7 Relative abundance of the six most abundant fungal genera from the dry (a) and the wet (b) tundra soil with statistically significant difference between control (green) and snow-manipulated (red) plots across all seasons (DESeq2, Benjamini-Hochberg correction, $P<0.05$ ). Green asterisk indicates significantly higher abundance in control plots, red asterisk indicates significantly higher abundance in snow-manipulated plots. The data represent the means with standard errors $(n=24)$

The overall prokaryotic community was dominated by Proteobacteria (29.2\%), Actinobacteria (17.7\%) and Acidobacteria (14.2\%). Alike the fungal communities, PCA showed highly dissimilar bacterial communities at dry and wet tundra sites (Fig. 3). Therefore, further analysis was done separately for the two sites. Approximately $30 \%$ of bacterial OTUs were present at both the dry site and the wet site (Additional file 4). Protebacteria constituted the most dominant phylum at both sites representing $28.9 \%$ at the dry site and $32.2 \%$ at the wet site. The relative abundance of Actinobacteria was $23.4 \%$ at the dry site and smaller at $14.6 \%$ at the wet site. OTUs assigned to bacteria involved in nitrification process, ammonia-oxidizing $\left(P=2 \times 10^{-156}\right)$ and nitrite-oxidizing bacteria $\left(P=2 \times 10^{-118}\right)$, showed distinctively higher abundance at the wet site compared to the dry site (Additional file 7). For example, nitrite-oxidizing Nitrospira showed ten times relative abundance difference between the dry and the wet site (Fig. 2). In contrast, OTUs assigned to nitrogen-fixing bacterial taxa (e.g. Cyanobacteria, Rhizobium and Bradyrhizobium) showed significantly higher abundance $\left(P=5 \times 10^{-45}\right)$ at the dry site compared to the the wet site (Additional file 7). We did not observed any significant effect of season on entire prokaryotic community composition (Fig. 5) therefore we analyzed the response of prokaryotes to increased snow cover both for individual time points $(n=6)$ and for pooled samples across all time points $(n=24)$.

Bacterial communities were apparently less influenced by the increased snow cover than fungi. Snow-manipulated plots and control plots shared 57 and $60 \%$ of bacterial OTUs at the dry and the wet sites, respectively
(Additional file 4), shared OTUs were represented by 98.5\% of sequences. Significant differences in abundance between treated and control plots were detected for three out of the thirty most abundant bacterial OTUs, both for the dry and the wet sites (Additional file 8). At the dry site two OTUs assigned to the Acidothermaceae family showed significant decrease $(P=0.026$ and $P=0.026)$ in their abundance in response to the treatment. Whereas at the wet site two OTUs assigned to the class Acidobacteria showed significantly positive response $(P=0.048$ and $P=0.031)$ to increased snow cover. ANOSIM analysis revealed that the OTU composition was significantly different between the prokaryotic communities only at the dry site $(\mathrm{R}=0.37, P=0.01)$, and not at the wet site $(\mathrm{R}=0.33$, $P=0.07)$. RDA of the prokaryotic community indicated that snow manipulation treatment explained 4.6 and $7.4 \%$ of community variability at the dry and the wet site, respectively (Fig. 5). PCA of the bacterial communities at both sites showed less clear distinction between treatment and control compared to fungal communities (Fig. 6).

Archaea represented on average 0.6 and $2.3 \%$ of the prokaryotic community at the dry and the wet site, respectively. Archaea showed significantly higher relative abundance at the wet site compared to the dry site $\left(P=4 \times 10^{-15}\right)$, however, we did not find any significant differences in their abundance between control and snow-manipulated plots (Additional file 9).

\section{Discussion}

\section{Microbial communities of dry and wet tundra soil}

Dry and wet tundra sites located $200 \mathrm{~m}$ apart showed pronounced differences in fungal and bacterial community 
structure and diversity consistent with differences in key soil chemical properties (Fig. 3), which is in accordance with previous observations from permafrost-affected soils [43, 99]. Besides abiotic soil properties, plant species/litter amount and quality affect tundra soil microbial communities [21, 91]. As different plant communities dominated the dry and the wet sites, we are unable to differentiate between the main drivers of the observed differences. Bacterial diversity almost doubled at the wet site as compared to the dry site whereas moist conditions negatively affected fungal diversity and biomass (Fig. 1). In accordance, water saturation has unfavorable effect on soil fungal diversity and abundance in Arctic tundra soils [44, 98].

Fungal community composition on order and phylum levels differed substantially between the dry and the wet sites (Fig. 2). At the dry site, the majority of identified sequences belonged to Ascomycota with the most abundant order Helotiales reported as a dominant fungal group in Arctic soils [28, 30, 89]. Interestingly, Basidiomycota dominated the wet site (Fig. 2). With respect to functional groups, ectomycorrhizal fungi showed highest relative abundance at both sites, followed by lichenized fungi at the dry site and saprotrophic fungi at the wet site (Fig. 4), which is in accordance with a study from Alaskan tundra [41]. We conclude that ectomycorrhizal and saprotrophic fungi were more abundant at the wet site whereas conditions at the dry site favored lichenized fungi (Fig. 4a). However, taking fungal biomass at the individual sites into consideration, the dry site harbored a higher amount of ectomycorrhizal and saprotrophic fungi compared to the wet site (Fig. 4b), despite their lower sequence proportion. The higher proportion of lichenized fungi in dry tundra and almost no occurrence in wet tundra are likely due to denser vascular vegetation at the wet site, which outcompeted lichens preferring poorly vegetated habitats [25]. At the wet site ectomycorrhizal fungi distinctively dominated over saprotrophs likely due to more favorable soil conditions and increased shrub cover (e.g. of Salix) providing roots available for mycorrhizal colonization. Furthermore, mycorrhizal fungi can outcompete microbial decomposers for rhizosphere territory [53] or by decreasing nutrient availability in the soil [40], which may slow down SOM degradation and increase soil C storage [5]. Mycorrhizal fungi can also contribute to soil $\mathrm{C}$ storage by allocation of $\mathrm{C}$ from plants, as proposed by Clemmensen et al. [22]. However, it should be noted that comparisons of fungal functional groups in between the sites may be biased by the fact that the proportion of unidentified fungal taxa was higher at the dry site than at the wet site (Fig. 2).

Despite a large difference in bacterial diversity between the two sites (Fig. 1), bacterial community composition on phylum level showed rather minor differences between the dry and the wet sites (Fig. 2). Proteobacteria, Actinobacteria and Acidobacteria dominated at both sites in accordance with observations from Alaska and Svalbard [51, 52]. Nitrifying bacteria (ammonia-oxidizing and nitrite-oxidizing) significantly dominated at the wet site compared to the dry site (Additional file 7). This is in accordance with Alves et al. [2], who measured distinctively lower nitrification rates in dry soil compared to wet tundra soil. Contrary to nitrifying bacteria, nitrogen-fixing bacteria dominated at the dry site compared to the wet site. This was likely linked to a higher relative abundance of lichenized fungi at the dry site where nitrogen-fixing cyanobacteria form lichens, symbiotic relationship with lichenized fungi. Even though archaea represent only a minority of soil prokaryotes, in our study $0.6 \%$ in dry and 2.3\% in wet tundra (Additional file 9), their role in greenhouse gas exchange by tundra soils is crucial. Ecosystems in the northern hemisphere with underlain permafrost soil represent the largest natural source of methane on Earth [37] and formation of methane (methanogenesis) is the terminal process of anaerobic $\mathrm{C}$ degradation performed solely by archaeal methanogens. Previous studies have shown consistent links between methanogen abundance and methanogenesis in Arctic soils $[54,88]$ and our observations indicate that soil moisture will likely be a key determinant of archaeal abundance and thus methane production.

\section{Direct and indirect effects of experimental enhancement of snow cover on microbial communities}

Fungal and bacterial communities showed significant changes in response to short-term increased snow cover manipulation at both sites indicating high susceptibility and/or adaptability of Arctic soil microbes to climate change. Our findings are supported by previous studies on Arctic soils demonstrating fast increase in abundance of microbial functional genes involved in SOM decomposition [96] and enhanced litter decomposition rates [13, 20] as a result of short-term increase of snow pack. Interestingly, contrary to our hypothesis, the fungal community exhibited a stronger response to the manipulation compared to the bacteria (Fig. 5, Additional files 4, 5 and 8) even though bacteria are typically considered to have higher growth and turnover rates than fungi [80] thus possessing an ability to adapt faster to new conditions. To our knowledge, our study is the first to simultaneously analyze the response of fungal and bacterial communities in tundra soils to short-term climate change manipulations. However, our results find support by Semenova et al. [78] and Morgado et al. [58] who showed strong changes in fungal community composition as a response to elevated snow cover, and of Männistö et al. [57] who reported minor changes in bacterial communities under naturally elevated snow. It should be noted that the snow fence treatment has multiple direct (e.g. enhanced winter soil temperature, lowered soil temperature before and after snow melt, and elevated soil water content after snow 
melt) and indirect effects (e.g. shortened plant growing season due to late snow melt) on the microbial communities. It is difficult to disentangle the effect of these individual drivers on the microbial communities.

Deepened snow pack increased fungal biomass at the wet site and enhanced the diversity of fungi and bacteria at the dry site across all time points (Fig. 1). The effect on microbial diversity at the dry site was most pronounced at the beginning of the vegetative season, suggesting that higher and more stable temperatures during winter caused by increased snow pack (Additional file 2) may have a direct and positive effect on microbial metabolism and growth rates [16]. The increased snow pack likely prolonged the period in which a winter microbial community is able to build up. Higher abundance and diversity of microbes as a result of soil warming has been observed in different ecosystems [20, 69, 71, 96, 97] and increased microbial diversity is associated with the enhancement of various ecosystem processes including SOM decomposition $[18,68]$.

The most abundant fungal genera significantly affected by deepened snow were ectomycorrhizal Inocybe, Camarophyllus, Russula, Tomentella, and Cenococcum saprotrophic Chalara, Mycena, and Clavaria, saprotrophic yeast Rhodotorula, lichenized Peltigera and root-associated Archaeorhizomyces with uncertain ecological roles (Fig. 7). Inocybe represented the most abundant genus showing positive significant response to increased snow cover on both sites. Our observation contrasts Morgado et al. [58] and Semenova et al. [78] who observed a decline as well as Mundra et al. [61] showing no effect on abundance of Inocybe due to longterm snow manipulation. Ectomycorrhizal Russula and Cenococcum at the wet site and Tomentella at the dry site showed significantly higher abundance due to the treatment. Since fungi belonging to Russula, Cenococcum and Tomentella genera may possess decomposition abilities of complex soil organic matter $[15,26,31]$, our observations might be the result of higher organic matter decomposition rates associated with increased soil temperature under elevated snow cover. The increased abundance of Russula, Cenococcum and Tomentella in response to soil warming has been reported in several studies [30, 35, 41, 65, 66]. Increased snow cover at the wet tundra site positively affected saprotrophic Mycena and Clavaria. Fungi belonging to Mycena spp., which are able to degrade all the major components of plant litter [42], have been shown previously to increase as a response to soil warming $[4,81]$. Our findings are supported by Blok et al. [13] who observed increased microbial litter decomposition in deep-snow plots (in the same experimental plots as used in our study) and agree with observations from Svalbard where an increase in saprotrophic fungi was observed after 6 year of snow fence manipulation [61]. A higher abundance of fungi with decomposing abilities in the treated plots indicates that the decomposition processes in tundra soils may change under future enhanced snow cover. Deepened snow pack significantly increased abundance of ectomycorrhizal fungi at the wet tundra site (Fig. 4b). Higher richness and abundance of ectomycorrhizal fungi as a response to summer soil warming has been reported previously [23, 29], but snow fence treatment has rather shown a decline in this community $[58,61,78]$. An increase in arbuscular mycorrhizal fungi due to deeper snow pack was detected in October at the wet tundra site (Fig. 4a). To our knowledge there are no previous reports of response of arbuscular mycorrhizal fungi to increased snow cover in tundra ecosystem. Contrary to our hypothesis, we did not detect any significant changes in abundance of saprotrophic fungi and plant pathogens under the snow cover manipulation which is in agreement with Semenova et al. [78] who did not observe any changes in abundance of these fungal functional groups after 18 years of increased snow depth in tundra soil.

Even though the response of prokaryotic community to increased snow cover was distinctively smaller than the response of fungi, several bacterial OTUs showed significant changes in their relative abundance under the treatment. The most abundant bacterial OTUs with significant feedback to snow manipulation were assigned to the classes Acidobacteria, Actinobacteria, Sphingobacteria and Thermoleophilia (Additional file 8). Representative taxa belonging to Acidobacteria and Actinobacteria have plant-specific interactions and abilities to degrade complex carbon compounds including plant cellulose and hemicellulose or fungal chitin [6,34]. Acidobacteria and Actinobacteria are sensitive to environmental changes caused by increased snow cover [57, 73]. An abundant OTU assigned to Chitinophagaceae (Sphingobacteriia class), known as chitin degraders and hence able to decompose fungal cell wall material, responded positively to increased snow cover. In accordance, increased snow cover manipulation resulted in higher abundance of genes for enzymes involved in chitin utilization [73, 96]. Interestingly, the relative abundance of two abundant OTUs at the dry site assigned to thermo-tolerant cellulolytic Acidothermaceae decreased in response to the treatment. Our findings show changes in abundance of bacteria with polymer decomposing abilities, which indicates that increased snow cover can impact SOM decomposition processes driven not only by fungi, but also by bacteria. The archaeal community at the wet site showed decreased abundance due to snow fence treatment constantly across all sampling times, however, these changes were insignificant (Additional file 9). This contrasts Xue et al. [96] who reported higher archaeal abundance under snow fence treatment in a moist tundra.

\section{Conclusions}

We demonstrate here that microbial communities in tundra soil differ at a small spatial scale due to 
contrasting soil parameters - in this case closely linked to landscape type, drainage and plant communities. Our results show that short-term climate manipulation (within few years) affects fungal and bacterial communities with fungal communities exhibiting a stronger response compared to prokaryotes. Rapid changes of fungal communities in response to the manipulation indicate their susceptibility and/or adaptability to current fluctuating weather conditions and future long-term climate changes. Furthermore, the effects of enhanced snow were manifested after snow had melted. Our study also shows that sampling at different time points within one growing season is needed if we are to understand the responses of soil microbial community composition to future changing climate. We are aware of the limitations of microbial rDNA amplicon sequencing [70], therefore for better understanding of the short-term effect of increased snow cover on microbial communities, it would be necessary to complement the current data with analysis of metatranscriptomes or metaproteomes providing insight into functional roles of individual microbial taxa under the future climate warming.

\section{Additional files}

Additional file 1: Soil chemical properties. Data represent means and standard errors from four time points $(n=24)$. (PDF $11 \mathrm{~kb})$

Additional file 2: A) Daily mean temperatures in $5 \mathrm{~cm}$ soil depth in course of the year. The arrows indicate approximate soil sampling date. B) Monthly and yearly mean temperatures in degrees of Celsius in $5 \mathrm{~cm}$ soil depth in control and snow-manipulated dry and wet tundra sites. (PDF $315 \mathrm{~kb}$ )

Additional file 3: OTU accumulation curves expressed as the number of OTUs by number of reads from sequencing. (PDF $307 \mathrm{~kb}$ )

Additional file 4: Venn diagrams showing shifts in (a) fungal and (b) bacterial community composition. Proportion of shared and unique OTUs across four time points is displayed $(n=24)$. OTUs with $>0.01 \%$ abundance were considered as present. D-dry tundra, W-wet tundra, C-control, S-snow manipulation. (PDF $53 \mathrm{~kb}$ )

Additional file 5: Identification of the 30 most abundant fungal OTUs from dry and wet tundra soil according to UNITE database, their relative abundance in control (C) and snow manipulated plots (S) across the plant growing seasons (June, July, September and October) and seasonal average (SA). Data of relative abundance are expressed as means from 6 (24 for SA) replicates, standard errors are shown in italic. Statistically significant differences between control and snow manipulated plots in the individual seasons are highlighted (DESeq2, Benjamini-Hochberg correction, $p<0.05$ ). Abundance (\%) represents mean relative abundance in all samples from particular tundra type. A- Ascomycota, B- Basidiomycota. (PDF $237 \mathrm{~kb}$ )

Additional file 6: Heatmap depicting the relative abundances of the 20 most dominant fungal genera in dry (a) and wet (b) tundra soil in control (C) and snow-manipulated (S) plots across the seasons. The data represent mean abundances $(n=6)$. Statistically significant effect (DESeq2, Benjamini-Hochberg correction, $P<0.05$ ) between control (C) and snow-manipulated (S) plots in the individual seasons is indicated by asterisk. The color code relates to each OTU independently and indicates the relative abundance of each OTU where 100 (red) means the sample with the highest relative abundance for the specific OTU. (PDF $185 \mathrm{~kb}$ )
Additional file 7: Proportion of sequences belonging to different bacterial functional groups in dry (D) and wet $(\mathrm{W})$ tundra soil in control (C) and snow-manipulated (S) plots. The data represent the means with standard errors $(n=6)$. (PDF $51 \mathrm{~kb}$ )

Additional file 8: Identification of the 30 most abundant bacterial OTUs from dry and wet tundra soil according to SILVA database, their relative abundance in control (C) and snow manipulated plots (S) across the plant growing seasons (June, July, September and October) and seasonal average (SA). Data of relative abundance are expressed as means from 6 (24 for SA) replicates, standard errors are shown in italic. Statistically significant differences between control and snow manipulated plots in the individual seasons are highlighted (DESeq2, Benjamini-Hochberg correction, $p<0.05)$. Abundance (\%o) represents mean relative abundance in all samples from particular tundra type. (PDF $147 \mathrm{~kb}$ )

Additional file 9: Relative abundance of archaea in prokaryotic sequence pool in dry (A) and wet (B) tundra soil in control (green) and snow-manipulated (red) plots by season and as a seasonal average (SA). The data represent the means with standard errors $(n=6)$, for seasonal average $(n=24)$. (PDF $57 \mathrm{~kb})$

\section{Abbreviations}

ANOSIM: Analysis of similarity; C: Carbon; N: Nitrogen; OTU: Operational taxonomic unit; PCA: Principal component analysis; PCR: Polymerase chain reaction; RDA: Redundancy analysis; SOC: Soil organic carbon; SOM: Soil organic matter

\section{Acknowledgments}

We would like to acknowledge Arctic Station (Qeqertarsuaq, Disko Island) for providing facilities and we thank Spire Maja Kiersgaard for field assistance. We gratefully thank Erland Bååth and Johannes Rousk for allowing us to use their laboratory equipment and technical expertise to obtain our ergosterol data, Anders Michelsen for help with the soil chemical analyses, and Anders Michelsen and Carsten Suhr Jacobsen for comments to an earlier version of the manuscript.

\section{Authors' contributions}

$\mathrm{BE}$ conceived the snow fence project, JV was responsible for collecting soil samples, extracting ergosterol, isolating DNA and preparing samples for $16 \mathrm{~S}$ rRNA gene and ITS amplicon sequencing, bioinformatics and statistical analyses, data interpretation and writing up the manuscript. BE and AP edited the manuscript and provided direct feedback to JV during the writing of the manuscript. All authors read and approved the final manuscript.

\section{Funding}

This work was funded by a grant to Center for Permafrost (CENPERM) from the Danish National Research Foundation (CENPERM DNRF100) and Danish Geocenter Grant (5298507).

\section{Availability of data and materials}

Sequencing data are available in MGRAST public database (http:// metagenomics.anl.gov/, dataset numbers 4782666.3 and 4782667.3).

\section{Ethics approval and consent to participate}

Not applicable

\section{Consent for publication}

Not applicable

\section{Competing interests}

The authors declare that they have no competing interests.

\section{Author details}

${ }^{1}$ Center for Permafrost (CENPERM), Department of Geosciences and Natural Resource Management, University of Copenhagen, Copenhagen, Denmark. Department of Geochemistry, Geological Survey of Denmark and Greenland (GEUS), Copenhagen, Denmark. ${ }^{3}$ Ecology Department, Climate and Ecosystem Sciences, Lawrence Berkeley National Laboratory, Berkeley, CA, USA. ${ }^{4}$ Department of Biology, University of Copenhagen, Copenhagen, Denmark. 


\section{Received: 5 March 2019 Accepted: 24 August 2019}

\section{Published online: 18 September 2019}

\section{References}

1. Abarenkov K, Henrik Nilsson R, Larsson K-H, Alexander IJ, Eberhardt U, Erland $S$, et al. The UNITE database for molecular identification of fungi - recent updates and future perspectives. New Phytol. 2010;186:281-5.

2. Alves RJE, Wanek W, Zappe A, Richter A, Svenning MM, Schleper C, Urich T. Nitrification rates in Arctic soils are associated with functionally distinct populations of ammonia-oxidizing archaea. ISME J. 2013;7:1620-31.

3. Aronesty E. Comparison of sequencing utility programs. Open Bioinforma J. 2013;7:1-8.

4. Asemaninejad A, Thorn RG, Lindo Z. Experimental climate change modifies degradative succession in boreal peatland fungal communities. Microb Ecol. 2017;73:521-31.

5. Averill C, Hawkes CV. Ectomycorrhizal fungi slow soil carbon cycling. Ecol Lett. 2016;19:937-47.

6. Barret M, Morrissey JP, O'Gara F. Functional genomics analysis of plant growth-promoting rhizobacterial traits involved in rhizosphere competence. Biol Fertil Soils. 2011;47:729.

7. Bååth E. Estimation of fungal growth rates in soil using C-14-acetate incorporation into ergosterol. Soil Biol Biochem. 2001;33:2011-8.

8. Bálint M, Schmidt P-A, Sharma R, Thines M, Schmitt I. An Illumina metabarcoding pipeline for fungi. Ecol Evol. 2014;4:2642-53.

9. Bellgard SE, Williams SE. Response of mycorrhizal diversity to current climatic changes. Diversity. 2011;3:8-90.

10. Bengtsson-Palme J, Ryberg M, Hartmann M, Branco S, Wang Z, Godhe A, et al. Improved software detection and extraction of ITS1 and ITS2 from ribosomal ITS sequences of fungi and other eukaryotes for analysis of environmental sequencing data. Methods Ecol Evol. 2013;4:914-9.

11. Biederbeck VO, Campbell CA. Soil microbial activity as influenced by temperature trends and fluctuations. Can J Soil Sci. 1973;53:363-76.

12. Bintanja $R$, Selten FM. Future increases in Arctic precipitation linked to local evaporation and sea-ice retreat. Nature. 2014;509:479-82.

13. Blok D, Elberling B, Michelsen A. Initial stages of tundra shrub litter decomposition May be accelerated by deeper winter snow but slowed down by spring warming. Ecosystems. 2015;19:155-69.

14. Bond-Lamberty B, Thomson A. Temperature-associated increases in the global soil respiration record. Nature. 2010;464:579-82.

15. Bödeker ITM, Nygren CMR, Taylor AFS, Olson Å, Lindahl BD. Classll peroxidase-encoding genes are present in a phylogenetically wide range of ectomycorrhizal fungi. ISME J. 2009;3:1387-95.

16. Brown JH, Gillooly JF, Allen AP, Savage VM, West GB. Toward a metabolic theory of ecology. Ecology. 2004;85:1771-89.

17. Buckeridge KM, Grogan P. Deepened snow alters soil microbial nutrient limitations in arctic birch hummock tundra. Appl Soil Ecol. 2008;39:210-22.

18. Cadotte MW, Dinnage R, Tilman D. Phylogenetic diversity promotes ecosystem stability. Ecology. 2012;93:S223-33.

19. Caporaso JG, Lauber CL, Walters WA, Berg-Lyons D, Huntley J, Fierer N, et al. Ultra-high-throughput microbial community analysis on the Illumina HiSeq and MiSeq platforms. ISME J. 2012;6:1621-4.

20. Christiansen CT, Haugwitz MS, Prieme A, Nielsen CS, Elberling B, Michelsen $A$, et al. Enhanced summer warming reduces fungal decomposer diversity and litter mass loss more strongly in dry than in wet tundra. Glob Chang Biol. 2016;23:406-20

21. Chu HY, Neufeld JD, Walker VK, Grogan P. The influence of vegetation type on the dominant soil Bacteria, archaea, and fungi in a low Arctic tundra landscape. Soil Sci Soc Am J. 2011;75:1756-65.

22. Clemmensen KE, Bahr A, Ovaskainen O, Dahlberg A, Ekblad A, Wallander H, et al. Roots and associated fungi drive long-term carbon sequestration in boreal forest. Science. 2013;339:1615-8.

23. Clemmensen KE, Michelsen A, Jonasson S, Shaver GR. Increased ectomycorrhizal fungal abundance after long-term fertilization and warming of two arctic tundra ecosystems. New Phytol. 2006;171:391-404.

24. Cooper EJ, Dullinger S, Semenchuk P. Late snowmelt delays plant development and results in lower reproductive success in the high Arctic Plant Sci. 2011;180:157-67.

25. Cornelissen JHC, Callaghan TV, Alatalo JM, Michelsen A, Graglia E, Hartley

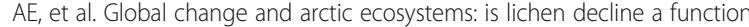
of increases in vascular plant biomass? J Ecol. 2001;89:984-94.
26. Courty P-E, Franc A, Garbaye J. Temporal and functional pattern of secreted enzyme activities in an ectomycorrhizal community. Soil Biol Biochem. 2010;42:2022-5.

27. D'Imperio L, Nielsen CS, Westergaard-Nielsen A, Michelsen A, Elberling B. Methane oxidation in contrasting soil types: responses to experimental warming with implication for landscape-integrated $\mathrm{CH} 4$ budget. Glob Chang Biol. 2017;23:966-76.

28. Dahl MB, Prieme A, Brejnrod A, Brusvang P, Lund M, Nymand J, et al. Warming shading and a moth outbreak reduce tundra carbon sink strength dramatically by changing plant cover and soil microbial activity. Sci Rep. 2017;7:16035.

29. Deslippe JR, Hartmann M, Mohn WW, Simard SW. Long-term experimental manipulation of climate alters the ectomycorrhizal community of Betula nana in Arctic tundra. Glob Chang Biol. 2011;17:1625-36.

30. Deslippe JR, Hartmann M, Simard SW, Mohn WW. Long-term warming alters the composition of Arctic soil microbial communities. FEMS Microbiol Ecol. 2012;82:303-15.

31. Durall D, Todd A, Trappe J. Decomposition of C-14-labeled substrates by ectomycorrhizal Fungi in association with Douglas-fir. New Phytol. 1994;127:725-9.

32. Edgar RC. UPARSE: highly accurate OTU sequences from microbial amplicon reads. Nat Methods. 2013;10:996-8.

33. Edwards AC, Scalenghe R, Freppaz M. Changes in the seasonal snow cover of alpine regions and its effect on soil processes: a review. Quat Int. 2007; 162-163:172-81.

34. Eichorst SA, Kuske CR, Schmidt TM. Influence of plant polymers on the distribution and cultivation of bacteria in the phylum Acidobacteria. Appl Environ Microbiol. 2011;77:586-96.

35. Fernandez CW, Nguyen NH, Stefanski A, Han Y, Hobbie SE, Montgomery RA, et al. Ectomycorrhizal fungal response to warming is linked to poor host performance at the boreal-temperate ecotone. Glob Change Biol. 2017;23:1598-609.

36. Friedlingstein $P$, Meinshausen M, Arora VK, Jones CD, Anav A, Liddicoat SK, et al. Uncertainties in CMIP5 climate projections due to carbon cycle feedbacks. J Clim. 2014;27:511-26.

37. Fung I, John J, Lerner J, Matthews E, Prather M, Steele LP, et al. Threedimensional model synthesis of the global methane cycle. J Geophy Res. 1991;96:13033-65.

38. Fukami T. Historical contingency in community assembly: integrating niches, species pools, and priority effects. Annu Rev Ecol Syst. 2015;46:1-23.

39. Gabriel C-E, Kellman L. Investigating the role of moisture as an environmental constraint in the decomposition of shallow and deep mineral soil organic matter of a temperate coniferous soil. Soil Biol Biochem. 2014:68:373-84.

40. Gadgil RL, Gadgil PD. Mycorrhiza and litter decomposition. Nature. 1971;233:133.

41. Geml J, Morgado LN, Semenova TA, Welker JM, Walker MD, Smets E. Longterm warming alters richness and composition of taxonomic and functional groups of arctic fungi. FEMS Microbiol Ecol. 2015;91:fiv095.

42. Ghosh A, Frankland JC, Thurston CF and Robinson CH Enzyme production by Mycena galopus mycelium in artificial media and in Picea sitchensis F1 horizon needle litter. Mycol Res 2003;107:996-1008.

43. Gittel A, Barta J, Kohoutova I, Schnecker J, Wild B, Capek P, et al. Site- and horizon-specific patterns of microbial community structure and enzyme activities in permafrost-affected soils of Greenland. Front Microbiol. 2014;5:14.

44. Grau O, Geml J, Pérez-Haase A, Ninot JM, Semenova-Nelsen TA, Peñuelas J. Abrupt changes in the composition and function of fungal communities along an environmental gradient in the high Arctic. Mol Ecol. 2017;26:4798-810.

45. Hobbie SE, Nadelhoffer KJ, Hogberg P. A synthesis: the role of nutrients as constraints on carbon balances in boreal and arctic regions. Plant Soil. 2002:242:163-70.

46. Hollesen J, Buchwal A, Rachlewicz G, Hansen BU, Hansen MO, Stecher O, et al. Winter warming as an important co-driver for Betula nana growth in western Greenland during the past century. Glob Chang Biol. 2015;21:2410-23.

47. Hugelius G, Strauss J, Zubrzycki S, Harden JW, Schuur EA, Ping C-L, et al. Estimated stocks of circumpolar permafrost carbon with quantified uncertainty ranges and identified data gaps. Biogeosciences. 2014;11:6573-93.

48. Hultman J, Waldrop MP, Mackelprang R, David MM, McFarland J, Blazewicz SJ, et al. Multi-omics of permafrost, active layer and thermokarst bog soil microbiomes. Nature. 2015;521:208.

49. Ihrmark K, Bödeker ITM, Cruz-Martinez K, Friberg H, Kubartova A, Schenck J, et al. New primers to amplify the fungal ITS2 region - 
evaluation by 454-sequencing of artificial and natural communities. FEMS Microbiol Ecol. 2012;82:666-77.

50. IPCC. Climate change 2013: the physical science basis. Contribution of working group I to the fifth assessment report of the intergovernmental panel on climate change. In: Stocker TF, Qin D, Plattner G-K, Tignor M, Allen SK, Boschung J, editors. Summary for Policymakers. Cambridge: Cambridge University press; 2013. p. 3-29.

51. Koyama A, Wallenstein MD, Simpson RT, Moore JC. Soil bacterial community composition altered by increased nutrient availability in Arctic tundra soils. Front Microbiol. 2014;5:516.

52. Lee S-H, Jang I, Chae N, Choi T, Kang H. Organic layer serves as a hotspot of microbial activity and abundance in Arctic tundra soils. Microb Ecol. 2013; 65:405-14.

53. Lindahl B, Stenlid J, Finlay R. Effects of resource availability on mycelial interactions and 32P transfer between a saprotrophic and an ectomycorrhizal fungus in soil microcosms. FEMS Microbiol Ecol. 2001;38: 43-52.

54. Lipson DA, Haggerty JM, Srinivas A, Raab TK, Sathe S, Dinsdale EA. Metagenomic insights into aaerobic metabolism along an arctic peat soil profile. PLoS One. 2013;8:e64659.

55. Love Ml, Huber W, Anders S. Moderated estimation of fold change and dispersion for RNA-seq data with DESeq2. Genome Biol. 2014;15:550.

56. Manly BF, Alberto JAN. Multivariate statistical methods: a primer. Boca Raton: CRC Press; 2016

57. Männistö MK, Kurhela E, Tiirola M, Häggblom MM. Acidobacteria dominate the active bacterial communities of Arctic tundra with widely divergent winter-time snow accumulation and soil temperatures. FEMS Microbiol Ecol. 2013;84:47-59.

58. Morgado LN, Semenova TA, Welker JM, Walker MD, Smets E, Geml J. Longterm increase in snow depth leads to compositional changes in arctic ectomycorrhizal fungal communities. Glob Chang Biol. 2016;22:3080-96.

59. Morgner E, Elberling B, Strebel D, Cooper EJ. The importance of winter in annual ecosystem respiration in the high Arctic: effects of snow depth in two vegetation types. Polar Res. 2010;29:58-74.

60. Muller K, Marhan S, Kandeler E, Poll C. Carbon flow from litter through soil microorganisms: from incorporation rates to mean residence times in bacteria and fungi. Soil Biol Biochem. 2017;115:187-96.

61. Mundra S, Halvorsen R, Kauserud H, Bahram M, Tedersoo L, Elberling B, et al. Ectomycorrhizal and saprotrophic fungi respond differently to long-term experimentally increased snow depth in the high Arctic. MicrobiologyOpen. 2016:5:856-69.

62. Natali SM, Schuur EAG, Rubin RL. Increased plant productivity in Alaskan tundra as a result of experimental warming of soil and permafrost. J Ecol. 2012;100:488-98.

63. Nielsen CS, Michelsen A, Ambus P, Deepagoda TKKC, Elberling B. Linking rhizospheric $\mathrm{CH}_{4}$ oxidation and net $\mathrm{CH}_{4}$ emissions in an arctic wetland based on ${ }^{13} \mathrm{CH}_{4}$ labeling of mesocosms. Plant Soil. 2017:412:201-13.

64. Oksanen J, Blanchet FG, Friendly M, Kindt R, Legendre P, McGlinn D et al. (2019). Vegan: community ecology package. R package version 2.5-5. https://CRAN.R-project.org/package=vegan

65. Parts K, Tedersoo L, Schindlbacher A, Sigurdsson BD, Leblans NIW, Oddsdóttir ES, et al. Acclimation of fine root systems to soil warming: comparison of an experimental setup and a natural soil temperature gradient. Ecosystems. 2018. https://doi.org/10.1007/s10021-018-0280-y.

66. Penton CR, Stlouis D, Cole JR, Luo Y, Wu L, Schuur EAG, et al. Fungal diversity in permafrost and tallgrass prairie soils under experimental warming conditions. Appl Environ Microbiol. 2013;79:7063-72.

67. Pold G, Billings AF, Blanchard JL, Burkhardt DB, Frey S, Melillo JM, et al. Long-term warming alters carbohydrate degradation potential in temperate Forest soils. Appl Environ Microbiol. 2016;82:6518-30.

68. Pold G, DeAngelis KM. Up against the wall: the effects of climate warming on soil microbial diversity and the potential for feedbacks to the carbon cycle. Diversity. 2013;5:409-25.

69. Pold G, Melillo JM, DeAngelis KM. Two decades of warming increases diversity of a potentially lignolytic bacterial community. Front Microbiol. 2015;6:480

70. Poretsky R, Rodriguez-R LM, Luo C, Tsementzi D, Konstantinidis TK. Strengths and limitations of $16 \mathrm{~S}$ rRNA gene amplicon sequencing in revealing temporal microbial community dynamics. PLoS One. 2014;9:e93827.

71. Priemé A, Blok D, Haugwitz MS, Voříšková J, Elberling B. Arctic soil microbial sensitivity to seasonal dynamics and climate change. In: Tate KR, editor.
Microbial Biomass: A Paradigm Shift in Terrestrial Biogeochemistry. London: World scientific; 2017. p. 275-307.

72. Quast C, Pruesse E, Yilmaz P, Gerken J, Schweer T, Yarza P, et al. The SILVA ribosomal RNA gene database project: improved data processing and webbased tools. Nucleic Acids Res. 2013;41:D590-D96.

73. Ricketts MP, Poretsky RS, Welker JM, Gonzalez-Meler MA. Soil bacterial community and functional shifts in response to thermal insulation in moist acidic tundra of Northern Alaska. Soil Discuss. 2016;2016:1-32.

74. Schimel JP, Bilbrough C, Welker JA. Increased snow depth affects microbial activity and nitrogen mineralization in two Arctic tundra communities. Soil Biol Biochem. 2004;36:217-27.

75. Schindlbacher A, Rodler A, Kuffner M, Kitzler B, Sessitsch A, ZechmeisterBoltenstern S. Experimental warming effects on the microbial community of a temperate mountain forest soil. Soil Biol Biochem. 2011;43:1417-25.

76. Schuur EAG, McGuire AD, Schädel C, Grosse G, Harden JW, Hayes DJ, et al. Climate change and the permafrost carbon feedback. Nature. 2015;520:171.

77. Semenchuk PR, Elberling B, Amtorp C, Winkler J, Rumpf S, Michelsen A, et al. Deeper snow alters soil nutrient availability and leaf nutrient status in high Arctic tundra. Biogeochemistry. 2015;124:81-94.

78. Semenova TA, Morgado LN, Welker JM, Walker MD, Smets E, Geml J. Compositional and functional shifts in arctic fungal communities in response to experimentally increased snow depth. Soil Biol Biochem. 2016; 100:201-9.

79. Schimel JP, Gulledge JM, Clein-Curley JS, Lindstrom JE, Braddock JF. Moisture effects on microbial activity and community structure in decomposing birch litter in the Alaskan taiga. Soil Biol Biochem. 1999;31: 831-8.

80. Six J, Frey SD, Thiet RK, Batten KM. Bacterial and fungal contributions to carbon sequestration in agroecosystems. Soil Sci Soc Am J. 2006;70:555-69.

81. Solly EF, Lindahl BD, Dawes MA, Peter M, Souza RC, Rixen C, et al. Experimental soil warming shifts the fungal community composition at the alpine treeline. New Phytol. 2017;215:766-78.

82. ter Braak CJF, Šmilauer P. Canoco Reference Manual and User's Guide: Software for Ordination (version 5.0). Ithaca: Microcomputer power; 2012

83. Tveit A, Schwacke R, Svenning MM, Urich T. Organic carbon transformations in high-Arctic peat soils: key functions and microorganisms. ISME J. 2013;7: 299-311.

84. van der Wal A, Geydan TD, Kuyper TW, de Boer W. A thready affair: linking fungal diversity and community dynamics to terrestrial decomposition processes. FEMS Microbiol Rev. 2013:37:477-94.

85. Větrovský T, Baldrian P. Analysis of soil fungal communities by amplicon pyrosequencing: current approaches to data analysis and the introduction of the pipeline SEED. Biol Fertil Soils. 2013;49:1027-37.

86. Voříšková J, Brabcová V, Cajthaml T, Baldrian P. Seasonal dynamics of fungal communities in a temperate oak forest soil. New Phytol. 2014;201:269-78.

87. Wahren CHA, Walker MD, Bret-Harte MS. Vegetation responses in Alaskan arctic tundra after 8 years of a summer warming and winter snow manipulation experiment. Glob Chang Biol. 2005;11:537-52.

88. Waldrop MP, Wickland KP, White lii R, Berhe AA, Harden JW, Romanovsky VE. Molecular investigations into a globally important carbon pool: permafrost-protected carbon in Alaskan soils. Glob Chang Biol. 2010;16:2543-54

89. Walker JF, Aldrich-Wolfe L, Riffel A, Barbare H, Simpson NB, Trowbridge J, et al. Diverse Helotiales associated with the roots of three species of Arctic Ericaceae provide no evidence for host specificity. New Phytol. 2011;191:515-27.

90. Walker MD, Walker DA, Welker JM, Arft AM, Bardsley T, Brooks PD, et al. Long-term experimental manipulation of winter snow regime and summer temperature in arctic and alpine tundra. Hydrol Process. 1999;13:2315-30.

91. Wallenstein MD, McMahon S, Schimel J. Bacterial and fungal community structure in Arctic tundra tussock and shrub soils. FEMS Microbiol Ecol. 2007:59:428-35

92. Wallenstein MD, McMahon SK, Schimel JP. Seasonal variation in enzyme activities and temperature sensitivities in Arctic tundra soils. Glob Chang Biol. 2009;15:1631-9

93. Weiss S, Xu ZZ, Peddada S, Amir A, Bittinger K, Gonzalez A, et al. Normalization and microbial differential abundance strategies depend upon data characteristics. Microbiome. 2017:5:27.

94. Welker JM, Fahnestock JT, Jones MH. Annual CO2 flux in dry and moist Arctic tundra: field responses to increases in summer temperatures and winter snow depth. Clim Chang. 2000;44:139-50. 
95. Wipf S, Rixen C. A review of snow manipulation experiments in Arctic and alpine tundra ecosystems. Polar Res. 2010;29:15.

96. Xue K, Yuan M, Shi ZJ, Qin Y, Deng Y, Cheng L, et al. Tundra soil carbon is vulnerable to rapid microbial decomposition under climate warming. Nat Clim Chang. 2016;6:595-600.

97. Yergeau E, Bokhorst S, Kang S, Zhou J, Greer CW, Aerts R, et al. Shifts in soil microorganisms in response to warming are consistent across a range of Antarctic environments. ISME J. 2012;6:692-702.

98. Zak DR, Kling GW. Microbial community composition and function across an arctic tundra landscape. Ecology. 2006;87:1659-70.

99. Zhang XF, Zhao L, Xu SJ Jr, Liu YZ, Liu HY, Cheng GD. Soil moisture effect on bacterial and fungal community in Beilu River (Tibetan plateau) permafrost soils with different vegetation types. J Appl Microbiol. 2013;114:1054-65.

\section{Publisher's Note}

Springer Nature remains neutral with regard to jurisdictional claims in published maps and institutional affiliations.

Ready to submit your research? Choose BMC and benefit from:

- fast, convenient online submission

- thorough peer review by experienced researchers in your field

- rapid publication on acceptance

- support for research data, including large and complex data types

- gold Open Access which fosters wider collaboration and increased citations

- maximum visibility for your research: over $100 \mathrm{M}$ website views per year

At $\mathrm{BMC}$, research is always in progress.

Learn more biomedcentral.com/submissions 